ZUZANNA ZALESKA

Instytut Nauk Politycznych UW

\title{
Perswazja w języku polityki
}

Granice mojego języka są granicami mojego świata.

L U D W I G W I T T G E N S T E I N

ęzyk jest tak bardzo obecny w życiu, że jego definiowanie i opisywanie wydaje się niekiedy zbyt oczywiste lub trudne. Dzięki językowi przekazywana jest kultura, wyróżniana tożsamość, możliwa komunikacja. Nic dziwnego zatem, że język odgrywa także istotną rolę w rzeczywistości politycznej, która jest przecież integralnym składnikiem funkcjonowania współczesnych społeczeństw. Tak, jak według tradycyjnych interpretacji polityka jest dążeniem do udziału we władzy lub do wywierania wpływu na jej podział ${ }^{1}$, tak nieodłączny element wywierania wpływu na tenże podział władzy stanowi perswazyjne użycie języka.

W niniejszej pracy przedstawię koncepcje funkcji, jakie pełni ludzki język, zwracając szczególną uwagę na te z nich, które mają znaczenie dla jego perswazyjności. Następnie zajmę się rolą języka etnicznego w komunikacji politycznej, aby przejść do ogólnego ujęcia perswazji w tekstach politycznych. Na zakończenie przedstawię to zjawisko na podstawie materiałów programowych partii politycznych oraz analizy składniowej zdań politycznych skonstruowanych w sposób zwiększający ich sugestywność.

Choć istnieje wiele koncepcji funkcji, jakie pełni język, to można wyodrębnić dwie podstawowe, które występują we wszystkich ujęciach. Z jednej strony jest bowiem język narzędziem porozumiewania się ludzi, spełnia

M. Weber, Polityka jako zawód i powołanie, przeł. A. Kopacki, P. Dybel, Kraków 1998. 
w tym zakresie funkcję komunikacyjną, a z drugiej strony jest reprezentatywny wobec rzeczywistości, będąc systemem znaków symbolicznych odzwierciedlających tę rzeczywistość ${ }^{2}$.

Znak jest tworzony intencjonalnie, w celu wywołania określonego zachowania, uczucia lub emocji. Stąd kolejną funkcją języka, związaną z jego reprezentatywnością, jest funkcja ewokacji w stosunku do odbiorcy oraz funkcja ekspresywna, jeśli chodzi o nadawcę ${ }^{3}$. Inne ujęcia przedstawiają je wspólnie jako sposoby podtrzymywania interakcji. Warto też zwrócić uwage na to, że system znaków językowych charakteryzuje się dwuklasowością. Pierwszą klasę stanowią połączone w słowa fonemy - podstawowe jednostki morfologiczne języka, które „same w sobie” nic nie znaczą. Druga klasa natomiast to słowa (jednostki z pierwszej klasy) połączone w zdania. Specyfika owej dwuklasowości polega jednak na tym, że znaczenie danego zdania nie jest prostą sumą znaczeń wyrazów użytych do jego budowy. Reguły łączenia słów w zdania oraz odczytywania ich znaczeń określa specyficzna dla każdego języka składnia. Michael A. K. Halliday wskazuje także na istotną z punktu widzenia tematu niniejszej pracy językową funkcję ideacyjną, która oznacza, że językowe wyrażenie sądów, opinii oraz idei w pewien sposób strukturalizuje doświadczenia wewnętrzne jednostki (zarówno nadawcy, jak i adresata) oraz powoduje, że wyzwolenie się spod narzuconej przez język konwencji interpretacyjnej wymaga pewnego wysiłku. Wątek ten omówię szerzej w dalszej części pracy.

Warto też zwrócić uwagę na koncepcję Noama Chomsky'ego dotyczącą uniwersalnego wyposażenia przedstawicieli Homo sapiens we wrodzone predyspozycje do przyswajania języka. Koncepcja ta wynika z założenia, że język powstał w wyniku biologicznej ewolucji gatunku. Chomsky wskazuje na pewne minimalne komponenty, które są wspólne dla wszystkich języków i nazywa je Uniwersalną Gramatyką . Wyróżnia się kilka podstawowych cech Uniwersalnej Gramatyki. Z punktu widzenia niniejszej pracy najistotniejsza wydaje się jej predykatywność, czyli to, że każdy język tworzy struktury umożliwiające orzekanie czegoś o czymś. Ta struktura, w połączeniu ze składnią, określa znaczenie danego zdania.

Drugą z podstawowych ról, jakie pełni język, jest funkcja komunikacyjna. W niektórych koncepcjach jest ona uznawana za wtórną wobec funkcji reprezentatywnej, inne zaś widzą w niej funkcję pierwotną. Podstawowym założeniem dla tego nurtu, zwanego pragmatycznym, jest stwierdzenie, że

Por. I. Kurcz, Psychologia języka i komunikacji, Warszawa 2000, s. 20.

Tamże, s. 21.

N. Chomsky, Zagadnienia teorii składni, przeł. I. Jakubczak, Wrocław 1982, s.17. 
gatunek Homo sapiens przejawia zdolność do decentracji. Decentracja określana jest jako umiejętność przyjęcia perspektywy partnera aktu komunikacyjnego, jest swego rodzaju empatią komunikacyjną. Ta zdolność rozumienia intencji innych stała się kamieniem milowym w rozwoju gatunku i przyczyniła się do powstania i złożoności języka.

Nie ulega wątpliwości, że komunikacja językowa jest najbardziej naturalnym i powszechnym sposobem porozumiewania się ludzi. Występuje ona także w działalności politycznej, czyli wszędzie tam, gdzie dochodzi do przedstawiania poglądów, wywierania wpływu, zdobywania poparcia i realizowania władzy. Najszerzej stosowanym narzędziem tej komunikacji jest język etniczny. Dzieje się tak dlatego, że jest on pierwotny wobec wszystkich innych używanych języków, umożliwia myślenie abstrakcyjne oraz komunikację interpersonalną. Dlatego stanowi dla sfery politycznej medium o szczególnym znaczeniu. Rzeczywistość polityczna, zapośredniczona przez język, staje się udziałem także tych jednostek, które nie miały do czynienia $\mathrm{z}$ jej elementami ${ }^{5}$. Dzieje się tak dzięki symbolizmowi języka - nie trzeba bezpośrednio doświadczyć przedmiotów i obiektów nazywanych w języku, aby przywołać je w pamięci lub aby zaistniały w świadomości. Oprócz owej oczywistej użyteczności, język etniczny umożliwia także określenie obszaru i zasięgu oddziaływania politycznego poprzez wyznaczenie wspólnoty komunikacyjnej, jest głównym czynnikiem definiowania tożsamości. Język etniczny to także elementarne narzędzie pracy urzędów użyteczności publicznej. Jako podstawowy środek komunikacji publicznej jest chroniony ustawowo ${ }^{6}$.

Jeśli chodzi o hegemoniczną komunikację polityczną, a więc taką, która odbywa się w jednorodnym środowisku, którego zarówno nadawcy, jak i odbiorcy posługują się i rozumieją jeden kod językowy, to mówić można o wzrastającym udziale przekazów o charakterze ikonicznym i symbolicznym. Jednak w odniesieniu do komunikacji politycznej in generalis wciąż największe znaczenie mają tradycyjne przekazy werbalne.

Znaczenie to docenia także koncepcja kontekstowości kultur, sformułowana przez Edwarda T. Halla ${ }^{7}$. Koncepcja ta lokuje kultury na kontinuum mocno-słabo uzależnione od kontekstu. Kultura uzależniona od kontekstu to taka kultura, w której część informacji zawarta jest w tle przekazu, dotyczącym wartości, ról, zasad, statusu społecznego, wyglądu, zachowań pozawer-

J. Fras, Komunikacja polityczna: wybrane zagadnienia gatunków i języka wypowiedzi, Wrocław 2005, s. 73.

Ustawa o języku polskim z 7 października 1999 r. z późniejszymi zmianami, dostępne: http://isip.sejm.gov.pl/servlet/Search?todo=open\&id=WDU19990900999 [20.01.2008].

J. Fras, dz. cyt., s. 77. 
balnych. Kultura słabo uzależniona od kontekstu to taka, w której większość informacji przekazywana jest bezpośrednio, w sposób werbalny.

Polską kulturę komunikowania się, według tej teorii, uznaje się za słabo związaną z kontekstem wypowiedzi. Przyczyną tego jest prawdopodobnie bliskość geograficzna i znaczny wpływ kultury niemieckiej (niskokontekstowa). Fakt ten znajduje odzwierciedlenie w bogactwie językowych środków wyrażania hierarchii i dystansu pomiędzy uczestnikami interakcji (explicite, bez uciekania się do niewerbalnych emblematów statusu społecznego). Dzięki temu podstawowym sposobem badania społecznych reprezentacji rzeczywistości, także politycznej, jest analiza językowego jej przetwarzania ${ }^{8}$. Głównym przedmiotem studiów w tym zakresie jest język polityki.

Pojęcie to definiuje w swoim artykule Bogdan Walczak. Jest to, według niego, „funkcjonalna odmiana języka ogólnego (...), stosowana w tekstach, które: (1) są wytwarzane przez środowisko polityków i ludzi z nimi związanych (...) oraz dziennikarzy specjalizujących się w problematyce politycznej, (2) są adresowane intencjonalnie do wszystkich użytkowników języka ogólnego, (3) dotyczą sfery polityki, (4) odznaczają się dominacją funkcji perswazyjnej (...)"

Widać zatem wyraźnie, że każde z przedstawionych ujęć teoretycznych, od najbardziej ogólnego, mówiącego o języku jako takim, poprzez język etniczny w komunikowaniu politycznym, aż po język polityki sensu stricto, zwraca się uwagę na perswazyjny aspekt funkcji tegoż języka. W najszerszym znaczeniu byłaby to owa zdolność języka do strukturalizowania doświadczeń i przeżyć wewnętrznych jednostki (wspomniana już funkcja ideacyjna ${ }^{10}$ ). Mówiąc o perswazyjności języka etnicznego i języka polityki w rozumieniu Walczaka, zauważyć należy wykorzystanie języka w politycznej komunikacji hegemonicznej jako narzędzia konstruowania rzeczywistości politycznej ${ }^{11}$. Sam Walczak zresztą dostrzega istotne znaczenie perswazyjności języka polityki, czyniąc z niej jego cechę dystynktywną.

Wydaje się zatem, że język w polityce służy realizacji celów i sprawowaniu władzy, posługując się w tym celu szeroko rozumianą perswazją. Pojęcie tak oto wyjaśnia Piotr Lewiński (przytaczam za Janiną Fras): „Perswazja to usiłowanie uzyskania realnego wpływu na sposób myślenia lub postępowania odbiorcy, jednakże nie drogą bezpośredniego rozkazu, lecz metodą pośrednią, poprzez podporządkowanie założonemu celowi wszystkich pozo-

Tamże, s. 78

B. Walczak, Co to jest język polityki, w: Język a kultura. Język polityki a współczesna kultura polityczna, J. Anusiewicz, B. Siciński (red.), Wrocław 1994.

10 I. Kurcz, dz. cyt., s. 21.

11 Por. J. Fras, dz. cyt., s. 85. 
stałych zachowań komunikacyjnych, które odbiorca byłby w stanie zrozumieć i właściwie zinterpretować"12.

Wyróżnić można cztery główne mechanizmy perswazji językowej, mianowicie: (1) Emocjonalizację odbioru, czyli przypisanie składnikom wypowiedzi negatywnych (odnośnie przeciwnika) lub pozytywnych (autoprezentacja) emocji, odwołanie do resentymentów; (2) Ustanowienie wspólnoty świata i wypowiedzi pomiędzy nadawcą i odbiorcą, co skraca dystans, ułatwia zrozumienie i przyjęcie komunikowanych treści. Efekt ten uzyskuje się między innymi dzięki użyciu języka potocznego i przywołaniu stereotypów; (3) Stosowanie uproszczonego, kategorycznego wartościowania, na zasadzie nieskomplikowanej opozycji (np. my-oni, dobry-zły); (4) Arbitralność definicji i ocen oraz takie przedstawianie problemu, że odbiorca ma poczucie bezalternatywności wyboru ${ }^{13}$. Spróbujmy odnaleźć te elementy we współczesnym języku polityki. Za przykład niech posłuży fragment exposé premiera Donalda Tuska:

„Staję dzisiaj przed wami, tu w polskim Sejmie, przed wami parlamentarzystami i przed całą polską opinią publiczną chyląc nisko głowę z poczuciem i pokory i dumy równocześnie. Pokory, bo mam świadomość jak nigdy dotąd w moim życiu, że rola, która przypadła mi i którą dzisiaj rozpoczynam jest rolą nadaną mi osobiście i całemu mojego gabinetowi przez Polaków. Jestem głęboko poruszony tą świadomością że słowa o służbie są dzisiaj słowami mocno brzmiącymi i bardzo prawdziwie. Ja dobrze wiem, i zwracam się tu do wszystkich naszych Rodaków, ja dobrze wiem, że ta zaszczytna służba, jaka przypadła mi w udziale i mojemu gabinetowi, to skutek, to efekt waszego wielkiego patriotycznego wysiłku" ${ }^{14}$.

Najbardziej jaskrawo widoczna jest emocjonalizacja wypowiedzi. Z jednej strony dokonuje się ona poprzez dobór tematyki. Już sam „patriotyczny wysiłek”, ,realizacja istotnej dla Rodaków roli” i „pełnienie zaszczytnej służby" sytuują tę interakcję wśród sytuacji podniosłych, dostojnych; takich, które nie pozostawiają obojętnym. Jednak nie tylko materialna zawartość wypowiedzi świadczy o jej emocjonalnym zabarwieniu. Donald Tusk, otwarcie opisując przeżywane przez siebie emocje, kreuje się na człowieka wzruszonego doniosłością chwili, którą chce dzielić ze słuchaczami.

W przytoczonym fragmencie odnaleźć też można inny mechanizm perswazji językowej - tworzenie wspólnoty między nadawcą a odbiorcą. Wprawdzie podstawowymi sposobami tworzenia takiej wspólnoty jest kon-

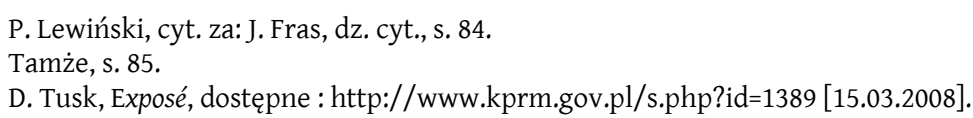


struowanie wypowiedzi opartej na stereotypowym obrazie świata, efekt ten można także osiągnąć, włączając adresatów do jakiejś większej, nobilitującej zbiorowości (do której i mówiący się zalicza), a stereotypizację odnosząc na przykład do narodowych mitów lub martyrologii. Z takim przypadkiem mamy do czynienia w wypowiedzi Tuska, gdy odnosi się do wszystkich Polaków i dokonuje generalizacji uznając, że misja tworzenia nowego gabinetu została mu powierzona decyzją wyborczą ogółu obywateli (po trosze każdy więc staje się ojcem i współuczestnikiem tego sukcesu).

Również dalsza wypowiedź Donalda Tuska dostarcza przykładów perswazyjnego zastosowania języka:

„Ja wierzę, że przed nami jest wielka szansa na dobrą zmianę. I chciałbym, jeśli państwo pozwolicie, opowiedzieć we wstępie do tego exposé o tym, co zdarzyło się w ciągu ostatnich dwóch lat. Co takiego stało się, że niespotykana dotąd w Polsce niepodległej liczba wyborców zdecydowała się pójść do wyborów, zdecydowała się stać czasami w wielogodzinnych kolejkach, co takiego stało się, że Polacy z taką determinacją, która zaimponowała także tym, którzy Polsce dobrze życzą, z taką determinacją postawili na zmianę"15.

W pierwszym akapicie cytowanego fragmentu polityk stawia odbiorcę w bezalternatywnej sytuacji - musi się on zgodzić na zaproponowaną definicję rzeczywistości. W tym wypadku dotyczy to określenia przyczyn mobilizacji wyborczej Polaków. Umieszczone niejako obok zasadniczego pytania o sytuację polityczną, zaproponowane przez premiera przyczyny wysokiej frekwencji, umykają racjonalnemu rozważeniu i zostają uznane za prawdziwe wraz z główną tezą o tym, że nadzwyczaj wysoka liczba osób wzięła udział w głosowaniu. Tymczasem nie musi być wcale prawdą, że popchnęła ich do tego chęć zmian, dania szansy innej opcji politycznej czy poczucie obywatelskiego sprawstwa aktu wyborczego. Na podstawie tej wypowiedzi wyborcy wypełniający kartę do głosowania i opowiadający się za zachowaniem status quo, głosujący z przyzwyczajenia, w każdej elekcji, a także kontestatorzy systemu, celowo wrzucający do urn głosy nieważne, zostali pominięci, a w najlepszym wypadku przypięto im łatkę orędowników zmian tak, jak gdyby żadna inna kategoria motywacji wyborczej nie istniała.

Kontynuując swoją wypowiedź w Sejmie, Donald Tusk dostarcza także argumentów za tym, że perswazyjność wypowiedzi można uzyskać poprzez zbudowanie tyleż prostej, co silnej opozycji my-oni:

„Chciałbym także powiedzieć, że chyba dobrze rozumiem, podobnie jak Platforma Obywatelska i Polskie Stronnictwo Ludowe, którym przyszło

15 Tamże. 
budować koalicję i nowy rząd, jakie oczekiwania polscy wyborcy mają wobec nowej władzy, dlaczego doprowadzili do zmiany już po dwóch latach. Uważam, i to dzisiaj powinniśmy sobie otwarcie powiedzieć, że Polacy zdecydowali się na zmianę władzy, ponieważ odczuwali coraz bardziej dotkliwie, że w ostatnich dwóch latach nie mogą zbudować w sobie zaufania do władzy, która nie ma zaufania do nich samych. Że, być może, pierwszym i głównym powodem, dla którego zmiana 21 października nastąpiła, był brak zaufania władzy - władzy, która ustąpiła - do własnych obywateli. Uważam też, że Polacy 21 października zdecydowali o zmianie, ponieważ ich marzeniem dwa lata temu i teraz, w dniu wyborów, była władza, która nie szuka konfliktów, a wręcz przeciwnie: szuka porozumienia wszędzie tam, gdzie to jest możliwe. Nie jesteśmy naiwni! Wiemy, że istnieją obiektywne konflikty interesów w każdym narodzie. Jesteśmy odpowiedzialni i w związku z tym rozumiemy, że, tak jak każdy wielki naród, tak i naród polski to różne wspólnoty: przekonań, wiary, interesów, wspólnoty etniczne, kulturowe. Tylko w przeciwieństwie do tych, którzy ustąpili miejsca w tych ławach, jesteśmy przekonani - a sądzę, że to przekonanie podziela przygniatająca większość Polaków - że zadaniem dobrej władzy jest rozwiązywanie i łagodzenie konfliktów, a nie żywienie się tymi konfliktami”.

Nietrudno odgadnąć, że owi my to obejmująca rządy ekipa, wymienieni są zresztą członkowie tworzącej się koalicji, Platforma Obywatelska i Polskie Stronnictwo Ludowe, zaś onymi określa się poprzedni rząd, cieszący się poparciem Prawa i Sprawiedliwości, Ligi Polskich Rodzin, a także Samoobrony (choć ugrupowania te nie są nazwane). Antagonizm jest faktycznie przedstawiony bardzo schematycznie, wyliczone także zostają błędy ustępującej opcji: brak zaufania władzy do obywateli oraz jej skłonność do wszczynania konfliktów. A contrario, świeżo zaprzysiężony gabinet, choć zdaje sobie sprawę z różnic interesów różnych grup społecznych, to jednak jest przedstawiany jako dobra alternatywa i sposób na pokojowe ich rozwiązywanie, a nie podsycanie. Na kanwie tak wyznaczonej przestrzeni publicznej określenie sympatii i politycznego poparcia wydaje się więcej niż oczywiste, a zatem osiągnięty został perswazyjny cel komunikatu.

O perswazyjności języka polityki pisze także Mirosław Karwat, nazywając go językiem natrętnym i naprzykrzającym się. Zwraca też uwagę na swobodne traktowanie logicznej spójności wypowiedzi, wartości informacyjnej komunikatu i podkreśla „szczególnie duże natężenie emocji”"16. Perswazyjne komunikaty polityczne często mają formę represyjną, obligują do

16 M. Karwat, Perswazja w tekstach politycznych - spojrzenie politologa, w: Język perswazji publicznej, K. Mosiołek-Kłosińska, T. Zgółka (red.), Poznań 2003, s. 113. 
uległości i podporządkowania, wzbudzają poczucie winy. Zabiegi te służą wymuszeniu konformizmu. Adresat jest zobowiązany przeprowadzić kalkulację, czy stawienie oporu jest opłacalne. Odbiorca niejednokrotnie stawiany jest w sytuacji oczywistości wyboru, sądu czy decyzji. Nie należy ulegać jednak złudzeniu, że język polityki jest oczywisty i jednoznaczny. Karwat dowodzi, że może być wprost przeciwnie. Niedookreśloność politycznych komunikatów jest swego rodzaju zabezpieczeniem przed oskarżeniami ze strony adwersarzy, a możliwość różnorakich interpretacji - zaworem bezpieczeństwa, który w trudnej sytuacji pozwala wybrnąć z opresji. Niewyraźność przekazu służy także powiększeniu zakresu oddziaływania - jest potencjalnie mniej osób, które komunikatem mogłyby poczuć się urażone. $\mathrm{Z}$ niejasnego komunikatu zabarwionego emocjonalnie przyszły wyborca zrozumie to, co będzie leżało w jego interesie. Jednocześnie jego nadawca łatwo może uniknąć spełnienia zawartych w nim obietnic, uciekając się do innej, wygodniejszej interpretacji. Przykładem takiej wypowiedzi jest przemówienie Tony'ego Blaira po atakach terrorystycznych na World Trade Center. Powszechnie zostało ono odebrane jako płomienna, zaangażowana mowa, porównywana nawet $\mathrm{z}$ oratorskim kunsztem Winstona Churchilla. Tymczasem pozbawiona emocji analiza teksu tego przemówienia pozwala wysnuć wniosek, że jest tak dalece niekontrowersyjne i nieostre, że mogłoby zostać pozytywnie odebrane przez wszystkich niemal słuchaczy ${ }^{17}$. Wieloznaczność jest zatem metodą przekazu tekstów politycznych. Jako przykład podana jest nazwa partii politycznej - Liga Polskich Rodzin. Z pozoru niewinna, ba! nawet przywołująca pozytywne skojarzenia, ma jednak dość poważne konsekwencje. Oto bowiem dzieli się rodziny na polskie i niepolskie ${ }^{18}$. Nie wiadomo jednak, co jest kryterium tak ostrego podziału: pochodzenie etniczne, poprawność światopoglądowa, uczestnictwo w kulturze? Nietrudno wyobrazić sobie dyskryminację (przynajmniej w warstwie retorycznej) płynącą z takiej kategoryzacji. Jednak gdyby zarzuty o nią zostały bezpośrednio sformułowane - można dookreślić ów podział przy pomocy kryterium obywatelstwa politycznego. W tym wypadku wieloznaczność nazwy czyni ją zarazem funkcjonalną (,polskość” formacji może pomóc w zjednaniu sympatii elektoratu) i bezpieczną.

Wielu przykładów na posługiwanie się Polska w tekstach politycznych dostarcza artykuł Katarzyny Mosiołek-Kłosińskiej ${ }^{19}$. Autorka zauważa, że

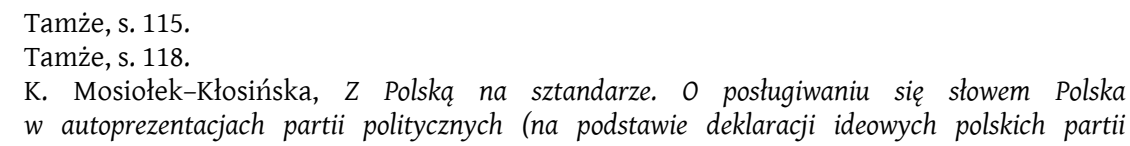


słowo to zazwyczaj jest nacechowane aksjologicznie, uzasadnia sens istnienia partii i służy budowaniu wspólnoty wartości z odbiorcą. Dzięki temu wzmacniane jest działanie perswazyjne tekstu. Przyczyniają się do tego także quasi-obiektywne opisy rzeczywistości (z Polską w tle), będące de facto jedynie jej kreacjami, zdania w czasie przyszłym, których prawdziwości nie sposób zweryfikować. Polska jest także sposobem autoprezentacji partii politycznych, która może się dokonywać w jednej z czterech kategorii ${ }^{20}$ : partie sukcesu (retoryka sukcesu), partie niespełnionego sukcesu (retoryka sukcesu), partie żądań (retoryka katastrofy), partie ratunku (retoryka katastrofy).

Partie posługujące się retoryką katastrofy używają słowa Polska w odniesieniu do pojęć takich jak likwidacja, ratunek, uzdrowienie. Wykorzystują rozbieżność między obecną sytuacją, w jakiej znajduje się kraj (a tę określają jednoznacznie negatywnie), a stanem hipotetycznego szczęścia, powodzenia i sukcesu (choć słowo to zazwyczaj nie pada). Skrajna odmiana tych partii partie ratunku sugerują wizję całkowitej zagłady, katastrofy i spisku. Stosują przy tym potoczne słownictwo i składnię, co zmniejsza dystans pomiędzy nadawcą i odbiorcą.

Retoryka sukcesu z kolei posługuje się słowem Polska najczęściej w kontekście rozwoju, zamożności, demokracji. Manipulacja sięga tak daleko, że nawet o porażce można mówić językiem zwycięstwa („Nie wszystkie grupy i regiony znalazły w sukcesie Polski swój własny sukces"21 - UW). Partie niespełnionego sukcesu, zgodnie z postulatem o represyjności języka polityki, oprócz pomyślności mówią także o groźbie i niebezpieczeństwie („Taki stan rzeczy to jedna $\mathrm{z}$ największych gróźb dla Polski” - SLD). Wspomniana już wieloznaczność języka polityki widoczna jest wtedy, gdy partie przywołują pojęcia związane z historią kraju (np. topos Sierpnia) oraz jego chrześcijańską tradycją (chrzest Polski) lub gdy mówią o przełomie. Ten ostatni zabieg służyć ma nowemu określeniu sytuacji i wzbudzeniu poczucia wyjątkowości. Oba rodzaje partii sukcesu odwołują się także do wspólnoty aksjologicznej, jaką jest Polska. Znamienny jest fakt, że wspólnotę tę buduje się unikając retoryki zagrożenia, lecz nazywając wyznawane wartości i zakładając, że dla odbiorców również są one ważne. Towarzyszy temu także uzurpowanie sobie powszechnego poparcia dla głoszonych poglądów oraz unikanie kwantyfikatorów szczegółowych.

O takich zabiegach stylistycznych pisze Aleksy Awdiejew, nazywając je wymuszonym wartościowaniem. U podstaw ich funkcjonalności, według au-

politycznych), w: Język narzędziem myślenia $i$ działania: materiały z konferencji zorganizowanej z okazji 100-lecia „Poradnika Językowego”, W. Gruszczyński (red.), Warszawa 2002.

20 Tamże, s. 121.

21 Ten i inne przykłady podaję za: K. Mosiołek-Kłosińską, dz. cyt., s. 122. 
tora, leży kluczowa dla komunikacji zasada kooperacji, czyli chęć osiągnięcia wspólnej korzyści informacyjnej ${ }^{22}$. Zasada ta wyjaśnia związek między użytą konwencją językową, a decyzją o przyjęciu informacji przez odbiorcę. Konsekwencje tego faktu są takie, że w warunkach niedoboru informacji za prawdziwe uznane zostanie nawet zdanie wypowiedziane $\mathrm{w}$ trybie przypuszczającym lub wyrażające hipotezę, nie zaś pewnik. Zjawisko „mimowolnej" akceptacji sądów potęguje budowa zdania, w którym ów sąd jest zawarty. Otóż informacja zawarta w tematycznej części wypowiedzi bezwzględnie uznawana jest za prawdziwą, ponieważ znajduje się ona na tle kognitywnym dalszej wypowiedzi. Wspólne rozumienie, podzielanie tego tła niezbędne jest dla kontynuowania interakcji. Odrzucenie zawartej w temacie presupozycji przez odbiorcę komunikatu wymaga rozpoczęcia metakonwersacji w celu ustalenia wspólnego tła kognitywnego. Oczywiście jest to możliwe w rozmowach osobistych lub w niewielkich grupach, gdzie bezpośredni kontakt interlokutorów nie jest utrudniony. Jednak w warunkach komunikacji masowej, a z taką przecież mamy najczęściej do czynienia w przypadku tekstów politycznych, opisane powyżej zjawisko dostarcza wielu okazji do manipulowania sądami odbiorców. Nie mają oni bowiem możliwości przerwania przekazu w celu doprecyzowania kognitywnych wątpliwości. Mogą jedynie słuchać dalej, przyjmując, choćby czasowo, presupozycje zawarte w temacie, lub przerwać odbiór treści, z którymi się nie zgadzają. Ta druga decyzja naraża jednak na całkowite pozbawienie się informacji i wyłączenie ze wspólnoty komunikacyjnej.

Umieszczanie sądów oceniających w temacie wypowiedzi, także wtedy, gdy nie są one podzielane przez wszystkich adresatów komunikatu, jest skrajnym nadużyciem konwencjonalnej siły języka. Przykładu takiej wypowiedzi dostarczył Jarosław Kaczyński na łamach tygodnika „Wprost” w 1993 roku: „Mamy nadzieję, że zachowanie się prezydenta okaże się propaństwowe"23. Sugeruje się tu bowiem, że w przeszłości prezydent zachowywał się antypaństwowo (presupozycja). Założenie takie jest potencjalnie sprzeczne z poglądami zwolenników prezydenta.

Jeszcze bardziej ukrytym przejawem nadużywania perswazyjnej siły języka są wymuszone implikatury. Implikatura może być określona jako presupozycja, której znaczenie odczytywane jest na podstawie kontekstu nawet jeśli nie wynika logicznie z wcześniejszych wypowiedzi. Aby jednak implikatura spełniła swoje zadanie i została odpowiednio zrozumiana, konieczne

22 A. Awdiejew, Wartościowanie wymuszone a szacunek dla odbiorcy $w$ dyskursie politycznym, w: Jezzyk a kultura..., s. 49-56.

23 Cytat z tygodnika „Wprost”, nr 93, cyt. za: A. Awdiejew, dz. cyt., s. 52. 
jest spełnienie trzech warunków ${ }^{24}$ : „zła wola” mówiącego, określenie przedmiotu wartościowania, drożność asocjacyjna.

Pierwszy z nich występuje zawsze wtedy, gdy mamy do czynienia z próbą sugerowania wartości czegoś „nie wprost”, dlatego, że wypowiadanie o kimś lub o czymś pozytywnych sądów nie wymaga użycia sugestii i zazwyczaj odbywa się bezpośrednio. Wobec tego można przyjąć, że u podstaw wypowiedzi aluzyjnych leżą negatywne intencje. Niespełnienie drugiego warunku, a więc niedookreśloność przedmiotu wartościowania, doprowadziłoby do sytuacji, w której odbiorca utożsamiłby się z nim osobiście lub uznał, że są nim obiekty oceniane przez niego pozytywnie. Zatem niezbędne jest wyrażenie przedmiotu wartościowania wprost. Drożność asocjacyjna natomiast oznacza możliwość i skłonność takiej interpretacji wypowiedzi, która skutkować będzie negatywnym sądem o podmiocie wartościowania (zgodnym z intencją nadawcy założoną w punkcie pierwszym).

Jak twierdzi autor, wypowiedzi powyższego typu są powszechnie obecne w dyskursie politycznym. Mieszczą się one bowiem w wieloznaczności wypowiedzi politycznej: nadawca może, ale nie musi mieć złej woli; drożność asocjacyjna sprzyja sądom negatywnym, ale nie wyklucza innych ocen. Warto zauważyć, że oba z przedstawionych sposobów konstruowania wypowiedzi godzą w poszanowanie poglądów odbiorcy, często bowiem w sposób nie w pełni świadomy zmuszają go do przyjęcia opinii, z którymi, być może, się nie utożsamia.

„Granice mojego języka są granicami mojego świata" - myślę, że w niniejszej pracy udało mi się pokazać, że Ludwig Wittgenstein miał rację. Czymże bowiem jest nadużywanie perswazyjnych właściwości języka, jeśli nie narzucaniem wizji i wyznaczaniem granic postrzeganego świata odbiorcom? Bogactwo struktur i form użycia języka czyni z niego elastyczne narzędzie komunikacji i odzwierciedlenia rzeczywistości, niesie jednak także ryzyko manipulacji i zniekształceń. Od roztropności nadawców i mądrości odbiorców zależeć będzie, czy wyznaczone językiem granice ułatwią wolność decyzji, czy też staną się krępującymi więzami propagandy.

Z U Z A N N A Z A L E S K A

$24 \quad$ Tamże, s. 53. 


\section{Persuading in the language of politics}

Language intermediates in reproducing culture, defines identity or enables communication. Thus, it is an important factor of social and political life as well. Politics, when defined in a traditional way, is a struggle for power or for exerting influence on it. One of its most successful methods is a proper usage of language and argumentation. That is why linguistics and its psychological background and effects are strictly relevant to this essay, where a language of politics will be presented and its persuasive features emphasised.

Firstly, a general, psycholinguistic perspective on the language composition, its communicational aspects for the persuasive effect are considered. The article focuses also on mother tongue in political communication and a persuasive side of political papers, speeches and texts. As a conclusion, the problem will be presented using samples of political parties' programmes or extracts from speeches. Detailed analysis of some politically involved sentences constitutes a proof of all the previous conclusions.

The first paragraph is based on the theories of Universal Grammar by Noam Chomsky and ideational function proposed by Michael Halliday. Communicative aspect of the language and its role as a mean of representation towards the reality are emphasised as well as some common features independent from nationality, geographical or historical background.

Although it is possible to distinguish some universal attributes of a language, it is still a mother tongue which is essential to political communication. It is prior to all other languages, defines identity and constitutes communicational assembly where politics is realised. The styles of such a communication in a homogeneous and heterogeneous environment are presented. Polish peculiarity and its effects are shown regarding the theory of contextual cultures by Edward T. Hall.

Then 4 main mechanisms of a linguistic persuasion with reference to the politics, according to M. Karwat and K. Mosiołek-Kłosińska, are presented.

Last analysis, after A. Awidejew, shows that persuasion can be executed not only in a speech or by a sequence of political appearances, but also by an abuse of words in a sentence. The linguistic mechanism and its consequences for the communicational process and cognitive background are described as well as relations between the partners. 